\title{
ANALÝZA ROZSAHU PROZKOUMANOSTI P̌̌EPADU PŘES TENKOSTĚNNÉ PŘELIVY S TROJÚHELNÍKOVÝM VÝŘEZEM
}

\author{
ANALYSIS OF THE EXPLORATION RANGE OF TRIANGULAR-NOTCH \\ THIN-PLATE WEIRS
}

\author{
Šimon Pospíšilik \\ ${ }^{1}$ Vysoké učení technické v Brně, Fakulta stavební, Ústav vodních staveb, Veveří 331/95, 60200 Brno, Česká republika
}

\begin{abstract}
Abstrakt
Za první významný experiment s přepadem přes tenkostěnný přeliv s trojúhelníkovým výřezem lze považovat Thomsonův $\mathrm{z}$ roku 1858 . V návaznosti na Thomsonovo měření byla provedena řada experimentů především v první polovině 20. století. Vybrané experimenty pak shrnul roku 1981 Shen. Článek se zabývá shromážděním dostupných publikací $\mathrm{k}$ tématu přepadu přes tenkostěnné přelivy s trojúhelníkovým výřezem do roku 2021 a analýzou rozsahu použitých geometrických parametrů a vlastností kapalin, kterými byly úhel výřezu, měřená výška vztažená ke koruně přelivu "přepadová výška", výška přelivu a teplota použité vody.
\end{abstract}

\section{Klíčová slova}

Tenkostěnný přeliv, trojúhelníkový výřez, přepad.

\begin{abstract}
As first significant experiment with an overflow over triangular-notch thin-plate weirs can be considered Thomson's from 1858. Following Thomson's measurements, a number of experiments were performed, especially in the first half of the 20th century. Selected experiments were then summarized in 1981 by Shen. The article deals with the collection of available publications on the topic of overflow over triangular-notch thin-plate weirs until 2021 and analysis of the range of used geometric parameters and liquid properties, which were triangular-notch angle, upstream gauged head above crest level "overflow head", height of the crest relative to the floor, and the temperature of the used water.
\end{abstract}

Key words

Thin-plate weir, triangular-notch, overflow.

\section{LITERÁRNÍ PŘEHLED}

Použití tenkostěnných přelivů s trojúhelníkovým výřezem pro měření průtoku vody navrhl roku 1858 Thomson [1]. Výsledky experimentů publikoval Thomson roku 1861 [2]. Ověření Thomsonem provedených experimentů provedl Barr [3] roku 1910. Experimenty rozšíríil o různé šířky prrítokového koryta a výšky přelivu. Na základě dat z Barrem provedených experimentů představil roku 1910 Strickland [4] vlastní vztah pro určení součinitele přepadu. Roku 1912 představil Yarnall [5] automatizované měření průtoku vody založené na tenkostěnném přelivu $\mathrm{s}$ trojúhelníkovým výřezem a plováku pro měření úrovně hladiny s automatickým zapisovačem. Kalibrací tenkostěnných přelivu s trojúhelníkovým výřezem pro měření průtoku př́mo v místě instalace přelivu se roku 1915 zabýval Cozzens [6], který se zaměřil i na vyjádření vlivu teploty vody při měření. Experimenty zabývající se vlivem teploty vody na součinitel přepadu publikoval roku 1915 Switzer [7]. Switzer uvádí vliv teploty na součinitel přepadu jako zanedbatelný (do $2 \%$ ) oproti dalším vlivům. Na základě porovnání vlastních experimentů a experimentů provedených Thomsonem a Barrem uvádí roku 1916 King [8] nový vztah pro výpočet průtoku vody přepadající přes tenkostěnné přelivy s trojúhelníkovým výřezem. Výzkum zaměřený na ověření a případné vytvoření nových vztahů pro výpočet průtoku vody přepadající přes tenkostěnné přelivy s pravoúhlým, lichoběžníkovým a trojúhelníkovým výřezem publikoval roku 1916 Cone [9]. Cone uvádí vztahy pro vybrané úhly trojúhelníkového výřezu a obecný vztah platný v předepsaném rozsahu. V roce 1917 pak Cone [10] uvádí návod pro praktické aplikace tenkostěnných přelivů s trojúhelníkovým výřezem. Stanovením součinitele přepadu 
a uvedením vztahu pro malé přepadové výšky se roku 1924 zabýval Barrett [11]. Rozměrovou analýzou experimentů provedených Barrem se roku 1927 zabýval Mawson [12]. Výzkum zaměřený na přesnost stanovení průtoku pomocí tenkostěnných přelivů s trojúhelníkovým výřezem doplněný o řadu provedených experimentů uvedl roku 1927 Yarnall [13]. Matematický důkaz o nejvyšší přesnosti tenkostěnného přelivu s trojúhelníkovým výřezem úhlu 90 oproti jiným úhlům výřezu uvedl roku 1927 O’Brien [14]. Experimenty zabývající se tvarem přelivné hrany tenkostěnných přelivů s trojúhelníkovým výřezem a použitím více výřezů stejného úhlu na tenkostěnném přelivu se roku 1929 zabývali Schoder a Turner [15]. Přesností Barrových a Yarnallových experimentů se roku 1929 zabýval Thorton [16]. V roce 1930 publikoval Greve [17] předběžné výsledky zabývající se vlivem viskozity, hustoty a povrchového napětí na přepad přes tenkostěnné přelivy s trojúhelníkovým výřezem. Obsahem výsledků byla experimentální měření s vodou, jako použitou kapalinou, a vztah pro výpočet hmotnostního průtoku. Experimentálním výzkumem s cílem zavedení energetické výšky přepadu do výpočtu průtoku vody přepadající přes tenkostěnné přelivy s trojúhelníkovým výřezem se roku 1931 zabýval Barrett [18]. Roku 1932 Greve [19] navázal na předešlé výzkumy z roku 1930 a doplnil je o vztahy popisující přepad přes tenkostěnné přelivy s trojúhelníkovým výřezem. Další experimenty na tenkostěnných přelivech s trojúhelníkovými výřezy zahrnující energetickou přepadovou výšku provedl roku 1932 Allerton [20]. Na základě Yarnallova výzkumu z roku 1927 vytvořil Smith [21] roku 1934 vztah zahrnující vliv kinematické viskozity $\mathrm{k}$ výpočtu průtoku horké vody přepadající přes tenkostěnné přelivy s trojúhelníkovým výřezem. Smihtův výzkum byl roku 1935 doplněn o recenze [22]. Experimentální měření na sadě tenkostěnných přelivů s trojúhelníkovým výřezem publikoval roku 1934 Wirak [23]. Roku 1937 provedl Numachi [24] výzkum na tenkostěnných přelivech s trojúhelníkovým výřezem úhlu $90^{\circ} \mathrm{s}$ cílem experimentálního vyhodnocení vlivu tvaru přelivné hrany. Praktickým využitím tenkostěnného přelivu s trojúhelníkovým výřezem úhlu $120^{\circ}$ se roku 1938 zabýval Hertzler [25]. V roce 1940 provedl Numachi [26], [27] experimenty zabývající se vlivem šírky přítokového koryta a výšky přelivu na součinitel průtoku. V roce 1941 rozšířil Numachi [28], [29] výzkum z roku 1940 o další experimenty. Na základě výzkumů z roku 1940 a 1941 Numachi [30], [31] roku 1942 představil vztah pro výpočet součinitele průtoku zahrnující vliv výšky přelivu a šířky přítokového koryta. Vliv viskozity a povrchového napětí na přepad přes tenkostěnné přelivy s trojúhelníkovým výřezem publikoval roku 1942 Lenz [32]. Roku 1945 Greve [33] doplil výzkum tenkostěnných přelivů s trojúhelníkovým výřezem o experimenty zaměřené na vliv viskozity vyjádřené Reynoldsovým číslem a povrchového napětí vyjádřeného Weberovým číslem. Pravidla instalace a měření pro stanovení průtoku vody přepadající přes tenkostěnné přelivy publikoval roku 1947 Viparelli [34]. Umístěním tenkostěnných přelivu do boxu se roku 1948 zabýval Numachi [35]. Výzkum zabývající se minimální délkou před přelivem publikoval Numachi [36] v roce 1951. Použitím tenkostěnných přelivů s trojúhelníkovým výřezem pro měření průtoku oleje se roku 1955 zabýval Itaya [37]. Porovnáním dat z experimentů provedených Grossim [38] roku 1961 s odvozením vlastního vztahu se roku 1962 zabýval Schlag [39]. Shrnutí do té doby známých poznatků o tenkostěnných přelivech s trojúhelníkovým výřezem publikoval roku 1981 Shen [40]. Dvě metody založené na měření výšky a šířky hladiny v místě výřezu tenkostěnných přelivů s trojúhelníkovým výřezem popsal roku 1986 Eli [41]. Použití tenkostěnných přelivů s trojúhelníkovým výřezem pro odběr vzorků vody popsali roku 1988 Cuttle a Mason [42]. Použitím boxů pro umístění tenkostěnných přelivů S trojúhelníkovým výřrezem se roku 1988 zabývali Milburn a Burney [43]. V roce 1989 publikoval Bos [44] informace popisující tenkostěnný přeliv s trojúhelníkovým výřezem, vztahy pro výpočet průtoku a omezující kritéria použití přelivu. Omezující podmínky a porovnání norem ISO 1438 [45] a BS 3680 [46] publikoval roku 1995 Herschy [47]. Na základě experimentálního měření a aplikace $\pi$-teorému dimenzionální analýzy vytvořil roku 2004 Ghodsian [48] nový vztah pro výpočet součinitele průtoku. Experimenty se složenými tenkostěnnými přelivy s trojúhelníkovým výřezem se roku 2005 zabýval Martínez [49], roku 2007 Piratheepan [50] a roku 2015 Ali [51]. Experimenty s tenkostěnnými přelivy s více trojúhelníkovými výřezy se v roce 2007 zabýval Ji [52] a v roce 2013 Ramamurthy [53]. Vliv úrovně hladiny dolní vody na měření průtoku vody přepadající přes tenkostěnný přeliv s trojúhelníkovým výřezem popsala v letech 2008 a 2010 Fejfarová [54], [55] a [56]. Stanovením vlivu tvarových odchylek tenkostěnných přelivů s trojúhelníkovým výřezem na měření průtoku vody zkoumala roku 2010 Klosíková [57]. Průběhem snížení hladiny před tenkostěnným přelivem s trojúhelníkovým výřezem a umístěním zařízení pro odečet úrovně hladiny se v letech 2013 a 2015 zabývala Kopečná [58], [59]. Porovnání tenkostěnných přelivů a stanovení chyby měření publikoval roku 2013 Martikno [60]. Kalibrací tenkostěnných přelivů s trojúhelníkovým výřezem za neustáleného proudění se roku 2013 zabýval Chanson [61], [62]. V roce 2013 Bautista-Capetillo, Robles, Júnez-Ferreira a Playán [63], [64] publikovali články doplněné o diskuse [65], [66], ve kterých se zabývají využitím technologie pomalé fotografie pro stanovení součinitele tenkostěnného přelivu s trojúhelníkovým výřezem. Vliv sklonu dna koryta na přepad přes tenkostěnné přelivy s trojúhelníkovým výřezem zkoumal roku 2014 Caroline [67]. Vlivem pravoúhlého a trojúhelníkového výřezu tenkostěnných přelivů na přepad se roku 2017 zabýval Adeyemi [68]. Vlivem hustoty vody (čisté a zabahněné) na součinitel průtoku přes tenkostěnné přelivy s trojúhelníkovým výřezem se zabýval roku 2017 Reddy [69]. Použitím tenkostěnných přelivů s trojúhelníkovými výřezy ve stísněných podmínkách se roku 2019 zabýval Hattab [70]. Tvarem trojúhelníkového výřezu a výřezy se zakřiveným rozšířením se roku 2019 zabýval Vatankhah [71]. Roku 2020 určil Vicena [72] minimální přepadovou výšku tenkostěnného přelivu s trojúhelníkovým výřezem. 


\section{ANALÝZA DAT}

Dostupné články, výzkumné zprávy a závěrečné práce zabývající se tématem přepadu přes tenkostěnné přelivy s trojúhelníkovým výřezem v období let 1858 až 2021 byly analyzovány na základě rozsahu geometrických parametrů a vlastností proudící vody. Vyhodnocen byl počet článků (Obr. 1, vlevo), rozsah přepadové výšky $h$ (Obr. 1, vpravo), rozsah poměru výšky přelivu $P$ k přepadové výšce, tedy $P / h$ (Obr. 2, vlevo), a rozsah teploty vody $T$ použité při experimentech (Obr. 2, vpravo) vztažený k úhlu trojúhelníkového výřezu $\alpha$. Na Obr. 1 vlevo je dále rozlišen počet článků splňující definici ostré přelivné hrany "sharp" (tloušt'ka přelivné hrany $\leq 2 \mathrm{~mm}$ ) [45] a nesplňující "blunt" (tloušt'ka přelivné hrany $>2 \mathrm{~mm}$ ).

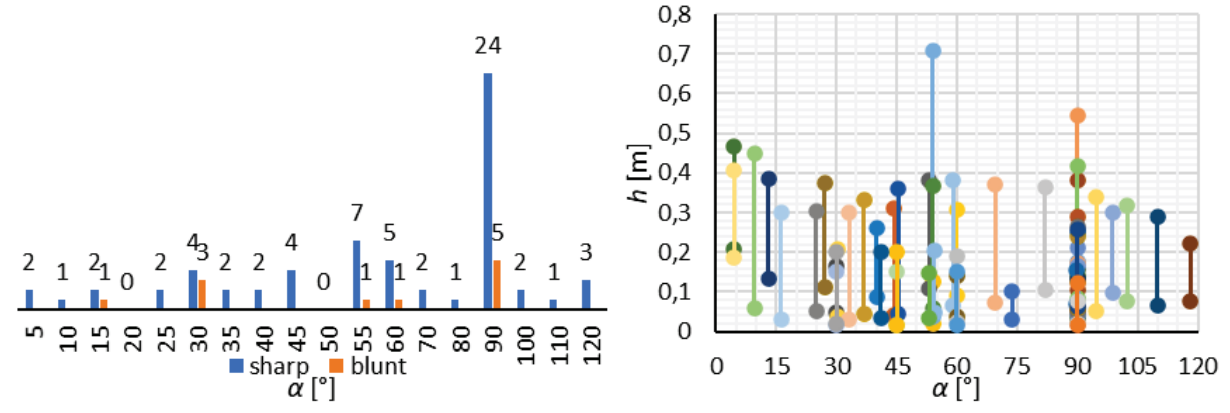

Obr. 1 Počet publikovaných článků (vlevo) a rozsah $h$ (vpravo) pro jednotlivé $\alpha$.
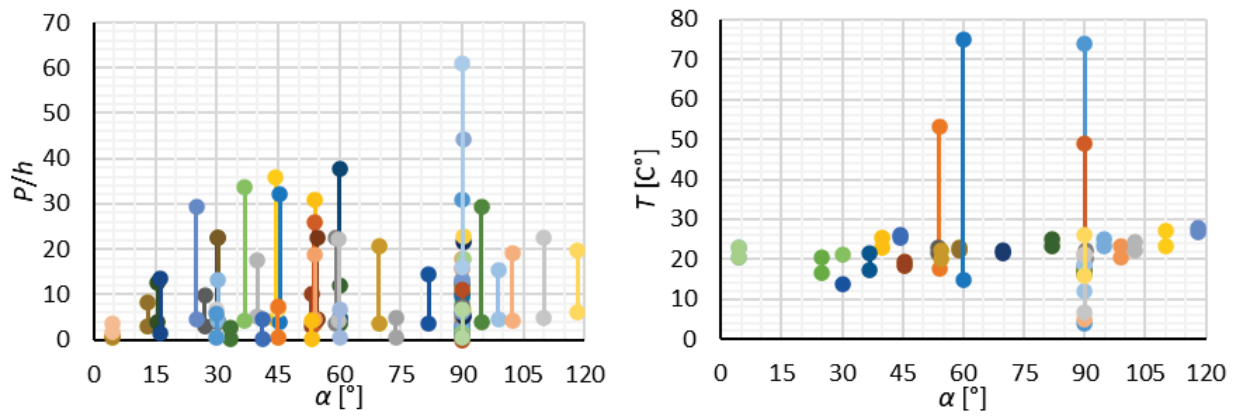

Obr. 2 Rozsah poměru $P / h$ (vlevo) a rozsah $T$ (vpravo) pro jednotlivé $\alpha$.

\section{ZÁVĚR}

Z analýzy dostupných článků, výzkumných zpráv a závěrečných prací je patrná nerovnoměrná publikační aktivita věnovaná různým úhlům výřezu tenkostěnných přelivů. Úhlům výřezu $30^{\circ}, 45^{\circ}, 55^{\circ}, 60^{\circ}$ a $90^{\circ}(\mathrm{Obr}$. 1 , vlevo) se věnovalo relativně velké množství autorů a jejich výsledky je možné do jisté míry mezi sebou porovnat. Z hlediska rozsahu přepadových výšek (Obr. 1, vpravo) lze pozorovat, že přelivy s úhlem výřezu v rozsahu od $10^{\circ}$ až do $90^{\circ}$ jsou prakticky prozkoumané v rozsahu přepadových výšek od $0,03 \mathrm{~m}$ až do $0,40 \mathrm{~m}$. Rozsah relativní výšky přelivu použitých při měření je s úhlem výřezu značně proměnný (Obr. 2, vlevo). Největší rozsah použité relativní výšky je při úhlu $90^{\circ} \mathrm{a} v$ oblasti úhlů výřezu $20^{\circ}$ až $60^{\circ}$. Nejvýraznější nerovnoměrnost rozsahu je u teploty přepadající vody (Obr. 2, vpravo), kde pouze v př́padě úhlů výřezu $55^{\circ}, 60^{\circ}$ a $90^{\circ}$ je vyhodnocen její vliv.

Z výše uvedeného lze konstatovat, že velká prozkoumanost přepadu je pouze u úhlu trojúhelníkového výřezu $90^{\circ}$. Přepad přes přelivy s úhlem trojúhelníkového výřezu $30^{\circ}, 45^{\circ}, 55^{\circ}$ a $60^{\circ}$ lze považovat za částečně prozkoumaný, v ostatních případech za relativně málo prozkoumaný.

Oblasti úhlů výřezu s nízkou prozkoumaností představují potencionální nejistoty při použití obecných postupů [40], [45] pro výpočet průtoku vody přepadající přes tenkostěnný přeliv s trojúhelníkovým výřezem. 


\section{Poděkování}

Příspěvek vznikl za podpory projektu FAST-J-21-7329 "Přepad přes tenkostěnné přelivy s trojúhelníkovým výřezem za malých přepadových výšek".

\section{Použité zdroje}

[1] THOMSON, J. On Experiments on the Measurement of Water by Triangular Notches in Weir Boards. In: Twenty-eight Meeting of the British Association for the Advancement of Science. London: John Murray, Albemarle street, 1858, s. 181-185.

[2] THOMSON, J. On Experiments on the Gauging of Water by Triangular Notches. In: Thirty-first Meeting of the British Association for the Advancement of Science. London: John Murray, Albemarle street, 1861, s. 151-158.

[3] BARR, J. Experiments Upon The Flow of Water Over Triangular Notches. Engineering. London, 1910, 89, 435-437, 470-473. ISSN 0013-7782.

[4] STRICKLAND, T. P. Mr. James Barr's Experiments Upon The Flow of Water Over Triangular Notches. Engineering. London, 1910, 90, 598. ISSN 0013-7782.

[5] YARNALL, D. R. The V-notch weir method of measurement. Journal of the American Society of Mechanical Engineers. New York, 1912, (34 p.2), 1479-1494.

[6] COZZENS, H. A. Flow Over V-Notch Weirs. Power. New York: Hill Publishing Co., 1915, $42(21), 714$.

[7] SWITZER, F. G. Test of the Effect of Temperature on Weir Coefficients. Engineering News. 1915, 73(13), 636-637.

[8] KING, H. W. Flow of water over right-angled V-notch weir. The Michigan Technic. 1916, 29(3), 189195.

[9] CONE, V. M. Flow through weir notches with thin edges and full contractions. Journal of Agricultural Research. Washington, D. C.: Department of Agricultural Research, 1916, 5(23), 1051-1113.

[10] CONE, V. M. Construction and Use of Farm Weirs. Farmers' Bulletin. Washington, D. C.: Department of Agricultural Research, 1917, (813), 1-18.

[11] BARRETT, J. M. A Study of the Flow of Water Over Triangular Weirs and the Determination of Coefficients of Discharge for Small Heads. Logan, 1924. Thesis. Utah Agricultural College.

[12] MAWSON, H. Applications of the principles of dimensional and dynamical similarity to the flow of liquids through orifices, notches and weirs. ARCHIVE Proceedings of the Institution of Mechanical Engineers 1847-1982. Institution of Mechanical Engineers, 1927, 112, 537-547. ISSN 0020-3483.

[13] YARNALL, D. R. Accuracy of the V-Notch-Weir Method of Measurement. The American Society of Mechanical Engineers. Baltimore: The Lord Baltimore Press, 1927, (48), 939-964.

[14] O'BRIEN, M. P. Least Error in V-Notch Weir Measurements When Angle Is 90 Degrees. Engineering News-Record. New York: McGraw-Hill Publishing Co., 1927, 98(25), 1030.

[15] SCHODER, E. W. a K. B. TURNER. Precise Weir Measurements. American Society of Civil Engineers. New York, 1929, 93, 999-1190.

[16] THORNTON, B. M. Measurement of Fluid Flow With Triangular Notches. The Power Engineer. London, 1929, 24, 313-315. ISSN 0370-0992.

[17] GREVE, F. W. Calibration of 16 Triangular Weirs at Prude. Engineering News-Record. New York: McGraw-Hill Publishing Company, 1930, 105(5), 166-167.

[18] BARRETT, F. B. The Flow of Water Over Triangular Weirs. Princeton, 1931. Thesis. Princeton University.

[19] GREVE, F. W. Flow of Water Through Circular, Parabolic, and Triangular Vertical Notch-Weirs. Engineering Bulletin Purdue University. Indiana: Purdue University, 1932.

[20] AllERTON, R. W. Flow of Water Over Triangular Weirs. Princeton, 1932. Thesis. Princeton University.

[21] SMITH, E. S. The V-Notch: Weir for Hot Water. The American Society of Mechanical Engineers. 1934, 56(9), 787-789.

[22] SMITH, E. S. The V-Notch Weir for Hot Water. Transactions of the American Society of Mechanical Engineers. New York: The American Society of Mechanical Engineers, 1935, 57, 249-250.

[23] WIRAK, L. R. An Investigation of the Flow of Water over Triangular Weirs of Different Angles. Princeton, 1934. Thesis. Princeton University.

[24] NUMACHI, F., T. KUROKAWA a E. TOTA. Einfluss der durch Uberlappungsherstellung bewirkten stromwarts unstetig hervorragenden Flache der Wehrkante eines rechtwinklig-dreieckigen Wehrs auf die Durchflusszahl. Transactions of the Society of Mechanical Engineers. Japan, 1937, 3(11), 174176. ISSN 2185-1123. Dostupné z: doi:doi.org/10.1299/kikai1935.3.11 174

[25] HERTZLER, R. A. Determination of a Formula for the 120-Deg V-Notch Weir. Civil Engineering. 1938, 
8(11), 756-757.

[26] NUMACHI, F., T. KUROKAWA a S. HUTIZAWA. Ueber den Ueberfallbeiwert elnes rechtwinkligdreieckigen Messwehrs. Journal of the Society of Mechanical Engineers. Japan, 1940, 43(275), 45. ISSN 2424-2675. Dostupné z: doi:doi.org/10.1299/jsmemag.43.275_45_2

[27] NUMACHI, F., T. KUROKAWA a S. HUTIZAWA. Ueber den Ueberfalbeiwert eines rechtwinkligdreieckigen Messwehrs. Transactions of the Japan Society of Mechanical Engineers. Japan, 1940, 6(22-3), 10-14. ISSN 2185-9485. Dostupné z: doi:doi.org/10.1299/kikai1938.6.22-3_10

[28] NUMACHI, F. a S. HUTIZAWA. Uber den Uberfallbeiwert eines Rechtwinklig-dreieckigen Messwehrs (2. Mitteilung). Journal of the Society of Mechanical Engineers. Japan, 1941, 44(286), 286. ISSN 2424-2675. Dostupné z: doi:doi.org/10.1299/jsmemag.44.286_5_1

[29] NUMACHI, F. a S. HUTIZAWA. Uber den Uberfallbeiwert eines rechtwinklig-dreieckigen Messwehrs (2. Mitteilung). Transactions of the Japan Society of Mechanical Engineers. Japan, 1941, 7(27-3), 59. ISSN 2185-9485. Dostupné z: doi:doi.org/10.1299/kikai1938.7.27-3_5

[30] NUMACHI, F. a S. HUTIZAWA. Ueber den Ueberfallbeiwert eines rechtwinkligdreieckigen Messwehrs (3. Mitteilung). Journal of the Society of Mechanical Engineers. Japan, 1942, 45(308), 725. ISSN 2424-2675. Dostupné z: doi:doi.org/10.1299/jsmemag.45.308_725_2

[31] NUMACHI, F. a S. HUTIZAWA. Uber den Uberfallbeiwert eines rechtwinklig-dreieckigen Messwehrs (3 Mitteilung). Transactions of the Japan Society of Mechanical Engineers. Japan, 1942, 8(33-3), $37-$ 40. ISSN 2185-9485. Dostupné z: doi:doi.org/10.1299/kikai1938.8.33-3 37

[32] LENZ, A. T. Viscosity and Surface Tension Effects on V-Notch Weir Coefficients. American Society of Civil Engineers. 1942, 351-374.

[33] GREVE, F. W. Flow of Liquids Through Vertical Circular Orifices and Triangular Weirs. Engineering Bulletin Purdue University. Indiana: Purdue University, 1945, 29(3).

[34] VIPARELLI, M. Sullo Stramazzo Thompson. In: Estratto da Atti Fondazione Politecnica Del Mezzogiorno. 3. Napoli, 1947, s. 1-24.

[35] NUMACHI, F. a I. SAITO. On Allawable Shortest Length of Channel for Triangular Notch. Journal of the Society of Mechanical Engineers. Japan, 1948, 51(357), 229-230. ISSN 2424-2675. Dostupné z: doi:doi.org/10.1299/jsmemag.51.357_229_2

[36] NUMACHI, F. a I. SAITO. On Allawable Shortest Length of Channel for Triangular Notch. Transactions of the Japan Society of Mechanical Engineers. Japan, 1951, 17(56), 1-3. ISSN 2185-9485. Dostupné z: doi:doi.org/10.1299/kikai1938.17.1

ITAYA, S. a T. TAKENAKA. Measurement of Oil Flow by means of $60^{\circ}$ Sharp-edged Triangular Weir. Transactions of the Japan Society of Mechanical Engineers. Japan, 1955, 21(101), 94-96. ISSN $2185-$ 9485. Dostupné z: doi:doi.org/10.1299/kikai1938.21.94

[38] GROSSI, P. Su uno stramazzo triangolare in parete sottile, libero, con angolo al vertice molto piccolo. L'Acqua. 1961(4), 99-100.

[39] SCHLAG, A. Note sur la mesure des débits pour déversoir triangulaire. La Tribune de Cebedeau. Liege, 1962, 15(218), 22-24. ISSN 0007-8115.

[40] SHEN, J. Discharge Characteristics of Triangular-notch Thin-plate Weirs: Studies of Flow of Water Over Weirs and Dams. Geological survey water-supply paper, 1617-B. Washington: United States Government Printing Office, 1981.

[41] ELI, R. N. V-Notch Weir Calibration Using New Parameters. Journal of Hydraulic Engineering. 1986, 112(4), 321-325. Dostupné z: doi:https://doi.org/10.1061/(ASCE)0733-9429(1986)112:4(321)

[42] CUTTLE, S. P. a D. J. MASON. A Flow-Proportional Water Sampler for Use in Conjunction with a VNotch Weir in Small Catchment Studies. Agricultural Water Management. Amsterdam: Elsevier Science Publishers B.V., 1988, 13, 93-99. ISSN 0378-3774.

[43] MILBURN, P. a J. BURNEY. V-notch weir boxes for measurement of subsurface drainage system discharges. Canadian Agricultural Engineering. 1988, 30(2), 209-212. ISSN 0045-432X.

[44] BOS, M. G. Discharge measurement structures. 3. Netherlands: International Institute for Land Reclamation and Improvement, 1989. ISBN 9070754150.

[45] ISO 1438-1:1980: Water flow measurement in open channels using weirs and Venturi flumes - Part 1: Thin-plate weirs. International Organization for Standardization, 1980.

[46] BS 3680-4A: 1981: Measurement of liquid flow in open channels — Part 4A: Method using thin-plate weirs. The British Standarts Institution, 1981.

[47] HERSCHY, R. General purpose flow measurement equations for flumes and thin plate weirs. Flow Measurement and Instrumentation. Great Britain: Elsevier Science, 1995, 6(4), 283-293. ISSN 09555986.

[48] GHODSIAN, M. Stage discharge relationships for triangular weir. International Journal of Civil Engineering. 2004, 2(1), 1-7. Dostupné také z: http://ijce.iust.ac.ir/article-1-1058-en.html

[49] MARTÍNEZ, J., J. RECA, M. T. MORILLAS. a J. G. LÓPEZ. Design and Calibration of a Compound 
Sharp-Crested Weir. Journal of Hydraulic Engineering. 2005, 131(2), 112-116. ISSN 1943-7900. Dostupné z: doi:10.1061/(ASCE)0733-9429(2005)131:2(112)

[50] PIRATHEEPAN, M., N. E. F. WINSTON a K.P.P. PATHIRANA. Discharge Measurements in Open Channels using Compound Sharp-Crested Weirs. Engineer: Journal of the Institution of Engineers. Sri Lanka, 2007, 40(3), 31-38. ISSN 1800-1122.

[51] ALI, A. A. M, M. IBRAHIM a A. I. DIWEDAR. The Discharge Coefficient for a Compound Sharp Crested V-Notch Weir. Asian Journal of Engineering and Technology. 2015, 3(5), 494-501. ISSN 2321 - 2462. Dostupné také z: https:/www.ajouronline.com/index.php/AJET/article/view/3008

[52] JI, K. Discharge Charakteristics of V-Shaped Multi-Slit Weirs. Montreal, 2007. Thesis. Concordia University.

[53] RAMAMURTHY, A. S., J. KAI a S. S. HAN. V-Shaped Multislit Weirs. Journal of Irrigation and Drainage Engineering. ASCE, 2013, 139(7), 582-585. Dostupné z: doi:10.1061/(ASCE)IR.19434774.0000574

[54] FEJFAROVÁ, M. Stanovení průtoku ostrohranným přelivem typu V v podmínkách ovlivnění hladinou dolní vody. 1. Brno: Vysoké učení technické v Brně, Fakulta stavební, Laboratoř vodohospodářského výzkumu, 2008.

[55] FEJFAROVÁ, M. Měrení průtoku za pomoci ostrohranných přelivů s podmínkách ovlivnění hladinou dolní vody. Brno, 2008. Thesis. Vysoké učení technické v Brně. Vedoucí práce Žoužela M.

[56] FEJFAROVÁ, M. Stanovení průtoku ostrohranným přelivem typu V za podmínek ovlivnění úrovně hladiny dolní vody. Brno, 2010. Thesis. Vysoké učení technické v Brně. Vedoucí práce Žoužela M.

[57] KLOSÍKOVÁ, B. Stanovení vlivu tvarových odchylek ostrohranného přelivu s výrezem tvaru V na jeho Q/h charakteristiku. Brno, 2010. Thesis. Vysoké učení technické v Brně. Vedoucí práce Žoužela M.

[58] KOPEČNÁ, M. Stanovení minimální protiproudní vzdálenosti hladinoměrného snímače od ostrohranného přelivu s výrezem ve tvaru V. Brno, 2013. Thesis. Vysoké učení technické v Brně. Vedoucí práce Žoužela M.

[59] KOPEČNÁ, M. Stanovení prüběhu snižení hladiny protiproudně před ostrohrannými přelivy s výřezem ve tvaru $V$. Brno, 2015. Thesis. Vysoké učení technické v Brně. Vedoucí práce Žoužela M.

[60] MARTIKNO, R., M. HUMAEDI, A. ASHAT, J. SITUMORANG, NOVIANTO a J. HADI. Evaluation of weirs calculation to estimate well capacity: a numerical study. In: 13th Indonesia International GEOTHERMAL Convention \& Exhibition 2013. Jakarta, 2013.

[61] CHANSON, H. a H. WANG. Unsteady Discharge Calibration of a Large V-Notch Weir: REPORT No. CH88/12. 1. Brisbane: The University of Queensland, 2012. ISBN 9781742720579. Dostupné také z: https://www.researchgate.net/publication/282355720_Unsteady_discharge_calibration_of_a_large_vnotch weir

[62] CHANSŌN, H. a H. WANG. Unsteady discharge calibration of a large V-notch weir. Flow Measurement and Instrumentation. Elsevier, 2013, 29, 19-24. Dostupné z: doi:https://doi.org/10.1016/j.flowmeasinst.2012.10.010

[63] BAUTISTA-CAPETILLO, C., O. ROBLES, H. JÚNEZ-FERREIRA a E. PLAYÁN. Discharge Coefficient Analysis for Triangular Sharp-Crested Weirs Using Low-Speed Photographic Technique. Journal of Irrigation and Drainage Engineering. American Society of Civil Engineers, 2013, 140(3). ISSN 0733-9437. Dostupné z: doi:10.1061/(ASCE)IR.1943-4774 .0000683

[64] BAUTISTA-CAPETILLO, C., O. ROBLES, H. JÚNEZ-FERREIRA a E. PLAYÁN. Closure to "Discharge Coefficient Analysis for Triangular Sharp-Crested Weirs Using Low-Speed Photographic Technique" by C. Bautista-Capetillo, O. Robles, H. Júnez-Ferreira, and E. Playán. Journal of Irrigation and Drainage Engineering. ASCE, 2015, 141(8), 1-2. Dostupné z: doi:https://doi.org/10.1061/(ASCE)IR.1943-4774.0000859

[65] MEHRZAD, M., S. KOUCHAKZADEH a M. BIJANKHAN. Discussion of "Discharge Coefficient Analysis for Triangular Sharp-Crested Weirs Using Low-Speed Photographic Technique" by C. Bautista-Capetillo, O. Robles, H. Júnez-Ferreira, and E. Playán. Journal of Irrigation and Drainage Engineering. ASCE, 2015, 141(8), 1-2. Dostupné z: doi:https://doi.org/10.1061/(ASCE)IR.19434774.0000789

[66] VATANKHAH, A. R. a P. PEYSOKHAN. Discussion of "Discharge Coefficient Analysis for Triangular Sharp-Crested Weirs Using Low-Speed Photographic Technique.” Journal of Irrigation and Drainage Engineering. ASCE, 2015, 141(8), 1-2. Dostupné z: doi:https://doi.org/10.1061/(ASCE)IR.19434774.0000858

[67] CAROLINE, L. L. a N. R. AFSHAR. Effect of Types of Weir on Discharge. Journal of Civil Engineering, Science and Technology. UNIMAS Publisher, 2014, 5(2), 35-40. ISSN 2462-1382. Dostupné z: doi:https://doi.org/10.33736/jcest.137.2014

[68] ADEYEMI, O. I., B. U. OREKO a J. ABAM. Experimental determination of the effect of notch shape on weir flow characteristics using constant head discharge apparatus. Asian Journal of Current Research. 
International Knowledge Press, 2017, 2(2), 55-64.

[69] REDDY, M. S. a Y. R. REDDY. Experimental Investigation on the Influence of Density of Fluid On Efficiency of V-Notch. International Journal of Advances in Scientific Research and Engineering. 2017, 3(9), 35-41. ISSN 2454-8006. Dostupné z: doi:https://doi.org/10.7324/\%20IJASRE.2017.32515

[70] HATTAB, M. H., A. M. MIJIC a D. VERNON. Optimised TriangularWeir Design for Assessing the Full-Scale Performance of Green Infrastructure. Water. MDPI, 2019, 4(11), 773-790. ISSN 20734441. Dostupné z: doi:https://doi.org/10.3390/w11040773

[71] VATANKHAH, A. R. a M. KHAMISABADI. Stage-discharge relationship for triangular and curvededge triangular weirs. Flow Measurement and Instrumentation. Elsevier, 2019, 69, 1-10. ISSN 09555986. Dostupné z: doi:https://doi.org/10.1016/j.flowmeasinst.2019.101609

[72] VICENA, D. Minimální přepadová výška u tenkostěnných přelivů s trojúhelníkovým výřezem. Brno, 2020. Thesis. Vysoké učení technické v Brně. Vedoucí práce Zachoval, M. 